\title{
A Study of the Humor in Mark Twain’s Classic Works
}

\author{
Ling Wang \\ School of Foreign Languages, Nanchang Normal University, Nanchang, China
}

\begin{abstract}
Mark Twain is a famous critical realist writer in the late nineteenth Century. Through combining humor and irony, he makes a relentless expose and criticism of the ugly phenomena in American social life. Humor is a unique way of thinking in his mind; he used humor to bring laugh to human. At the same time, he mercilessly criticized the ugly social reality, a profound reflection of the human condition in the world of metaphysical philosophy explores. The excellent satirical art in a number of his works showed, not only became an independent school at the time of the American literature, but also had a profound impact on the future of American literature. In this article, the author uses humor as a clue, and narrates the art of humor in Mark Twain's classic novels, the author will describe about the specific language and writing techniques from some classic novels of Mark Twain, to explore the art of humor embodied in the novel and the consequences of humor, so as to let the readers have a more intuitive and profound understanding of Mark Twain's novels, and also show the expression of noble tribute to Mark Twain for his outstanding achievement.
\end{abstract}

Index Terms - mark Twain, classical novels, humor

\section{INTRODUCTION}

\section{A. Overview of Research Background}

Mark Twain is the outstanding realistic writer and famous humorous writer in the late nineteenth Century in United States! He is good at using humor, as sharply, mercilessly, its creation will portray realism and romantic lyric harmony Unity. He wrote a lot of novels, most of these works are humorous strokes, the banter in truly see harmonic! The perfect unity of truth in Absurdity, His works were often funny and humor! Under the exaggeration of the surface, exposed the existence problem of human society in United States, humor reveals the beauty of good and evil in life, most incisive to express their love and praise, reflects Mark Twain's deep humanitarian concern to the society. The winner of Nobel Prize for literature Hemingway said that all modern American literature comes from the book called the adventures of Huckleberry Finn writing by Mark Twain, which is the best of all our books, never before, and not so far. Another Nobel Prize winner Faulkner has hailed him as the father of American Literature. These different evaluations show the great achievements made by Mark Twain in the history of American Literature, he is one of the greatest novelists in English Literature. The novels of Mark Twain truly represent the nature of the social life of his time. People who read his novels, in the narration of freely flowing style of writing, to appreciate the wisdom of the flash, or for the real description of the social reality, or a sharp criticism of the reality of society, or of life, human thinking, or the ultimate search on the world of human society. But Mark Twain's choice of narrative skills is out of the ordinary, he abandoned the general positive practice, his novels were born in the spirit of humor, humor became the main tone of the novel, his novel is a collection of depicting humorous painting, which hold obvious qualities of definite humor, profound criticism and vivid characteristic of his age. Humor is a unique way of thought for Mark Twain. As a talented orator with a wealth of experience, Mark Twain is good at applying humorous techniques of speech and recitation to the written language of novel. At the same time, with his rich reading and personal experience, Mark Twain grasped the current real life as well as the language features of different social groups in the history, so that more vivid and accurate outline of all kinds of a variety of characters, to enhance the sense of humor art. That is also an expression of humor by Mark Twain.

\section{B. The Reasons and Purposes of the Topic}

Since then, numerous studies have been completed such theme in literary field. Wang Xue (2014) has wrote an essay about the stylistic analysis of humor for Mark Twain's short stories, which concluded that humor can be produced by stylistic devices, and the reason why generation mechanism of humor produced by stylistic devices, which is helpful to realize and analyze the humorous phenomenon produced by stylistic devices. As to the humor theories in linguistics, this thesis introduces the Semantic Script Theory of Humor and Cooperative Principles. Chen Zhijing (2011) came up with some ideas in Age Literature that the humor of Mark Twain divided into three points: hyperbole, contrast and satire. He connected the humor with satire, which set a good example for later writers. Mark Twain' humor experience three steps: babyhood, maturity, grief, it also made his novels become more brilliant. Moreover, it was found by Anhui Literature that Mark Twain was a master of humor, and his works were famous for deeply ideology. From the aspects in characterization, language and storyline, Mark Twain polished the humorous features to give the novels new meaning and style. Great progress has been made in this field, different scholar had different idea with Mark Twain's novels, and 
all of their researches were good for the later learner. But uncertainties still exist in some studies. For example, there was an essay about humor of Mark Twain published on Journal of Guangxi University (Zeng xi ,1995) showed us the art of Mark Twain' novels, the author showed us the reality of America by using humorous descriptions, but it was mainly focus on the plots of Mark Twain' stories, less descriptions for humor, so it could not hold the title completely. Actually there is no perfect article in the world and will be always be some problems. Some essays could not express the theme clearly, and other several works could not use right sentences and grammar. I think the most serious problem was that the language was not concise in articles; it will make the works not be a authority. These problems will have a bad effect on one's work, so we should be more rigorous and careful.

It would seem that further investigations are needed in order to show Mark Twain's novels completely and deeply. As to humor, I think not only the features should be depicted, but also does the expression ways need to describe clearly. As far as I am concerned, the content of novels should not be retelling too much, or the article will be disorganized. Mark Twain's works had their own characteristic; we should grasp the main points of our subject, and pay more attention to the language expression.

But through the research on the related materials of Mark Twain's novels, the author finds that there is still some research value in the art of humor. First, although domestic scholars of Mark Twain's humor explored many aspects, but most of them think of Mark Twain's humor is only an art form, it is due to the novel narrative style. Second, most of the previous studies focused on the description of the phenomenon and the lack of theoretical discussion, in fact, from the perspective of theory, there are many aspects can study. Therefore, this article uses humor as a starting point, with a sense of humor as a clue, through this thesis to discuss Mark Twain's novels, through the formation of humor since the characteristic and the influence on later literature, in order to get a deeper level of understanding of the Mark Twain classic novels.

\section{The HuMOROUS EXPRESSION IN TWAIN MARK'S NOVELS}

\section{A. The Humorous Language Characters of Different Novels}

In 1865, Mark Twain published The Celebrated Jumping Frog of Calaveras County and put it over. At the end of the book, the main character Gum Smas, the biggest interest is gambling. He took great pains to train a frog, thinks it is the county's highest jumping frog. When he bet with a stranger, the frog is firmly sitting there, like a church, Smyth rather baffling. It is too late when he known the stranger lead bullets into the frog belly filling while it is not full of(Mark Twin, 2012). This work laid a Twain style - a humorous tone. Works not only laugh at the western people addicted to gambling, and at the same time, ridicule the public the vulgar boring. Mark Twin's humorous art is displayed through the language of the works. One of the language features is that his flexible use of dialect. Mark Twain had humble origins; he worked as compositors, seaman and navigator, also looking for gold, which led to his extensive contacts with the community, familiar with people's life and folk language. From the form of language, he works in colloquial language, simple sentence structure that is simple and plain, even does not conform to the rules of grammar; the spoken language belongs to the typical language in his novels. He skillfully use English to describe the story of people's daily life, in addition, his character of language with a strong the local dialect feature, limited to a particular historical period and specific region, make him more realistic. Most of his works of exotic humorous and funny, contains some jokes, comic plot wise products on, so reading his novels is very interesting. He flexibly used allegory, personification, metonymy, exaggeration, pun and other rhetorical devices in the novels; the works of the language has a magic power. For example, Mark Twain exaggerates to incredible the ascetic object. In this work, he ridiculed to polygamy, coined a man to marry seventy-two wives: "I made a wide bed in seven feet long and ninety-six feet. But I can't sleep, I found that seventy-two women were snoring, the deafening roars. Life is in danger! I see it in this way. When they breathe together, you can see the house wall really suck in, and then breathe out together; you will see the wall blow out." As for the exaggeration and misrepresentation, it would to be funny and humor.

\section{B. The Contradiction between the Subjective and the Objective Reality}

Building humor atmosphere needs to break logical thinking in the normal procedure to produce nervous anticipation and lost, then smile to it, so as to achieve the artistic effect of humor. Mark Twin's novels have made a very good interpretation of this. At the beginning of his works, it often allow readers intent the plot according to their own subjective imagine, then has produced an unexpected ending, but the ending can reflect the essence of life, so as to achieve the artistic effect of humor. Such as the short story of "Good Boy", the hero names Jacob Blevins, a little boy who is always "absolutely obedient to parents", "no matter how absurd they say, how unreasonable", "he is convinced that those children's stories about Sunday school". From the perspective of the reader's expectations, such a good child should have a happy family and a better future. But Mark Twin broke through the conventional logic, let Jacob "always unlucky, the things he met always are different from the good boy in the book should have meet", the most sad thing is, little Jacob was given a slap in the face by city councilor. When readers read here, the conventional logic is completely broken, the plot development completely. Mark Twin uses the way contains rich hyperbole humor, and sharply ironic Sunday school' education in the United States is the invisible killing machine to stifle students life. As it mentioned above the novella The Man Corrupted Hadley Burg, a stranger with a bag of gold, come to Hadley burg in the middle of the night to look for an unknown benefactor, and as a thank for helping by gold. However, for Hadley burg is a town 
fort with honest pride keep for three generations of good reputation, the not shaking the lofty flag for a bag of gold! But the ending is just the opposite way; all honest and clean has come to nothing in front of a bag of gold. The nineteen glossy decent citizens live in an anxious life every day, they all want to be the stranger's benefactor, and dream of the gold (Mark Twain, 2013). The result beyond reasonable seems to be absurd and perverse. But it is precisely such kind of ridiculous; people can really understand what the corruption of fancy is; people in the town are moral hypocrisy and greed. It exposed the bourgeois civilization so-called" true honest" that money is everything, and then construct a humorous tone.

\section{THE DifFERENT Forms OF HUMOR In TwaIN MARK'S NOVELS}

\section{A. Cheerful, Witty, and Relaxed Humor}

In Mark Twain's novels, the direct humorous effect is will produce a human smile, which is from the connotation of humor, it can be proved. In later nineteenth Century, the American people living in deep distress where racial discrimination prevailed! The social oppression of blacks' crackdown people! Countless pain all make people feel heavy repression, in order to reduce the stress, also to have a relaxed life, Mark Twain's humorous works will undoubtedly become a vast good the spice of life. From his first short novel The Celebrated Jumping Frog of Calaveras County, the humorous wind blew through the whole creation in his life. Although in his later creation, irony and sad tone became more and more serious, they also can not completely cover the light and bright humor(Mark Twain, 2013). Mark Twain's long representative novel the Adventures of Huckleberry Finn is in an extremely rich humor, it is very interesting when write a series of activities that Huck and Tom rescued Jim, showing more funny. According to the happiness principle of Freud's humor theory, as a reader, when we know Jim was shut, feeling nervous and hope they can be rescued by Huck as soon as possible, make Jim be a free man. In psychology, the heart is in the most urgent in rescue work, tense and hurried; there was no moment to delay. In the emotional, Expect that he will come up with a way to rescue them in time, when he came up with an excellent way that use a piece of wood, so that Jim can drill out from the inside, the reader would be relaxed, but an unexpected things happened again, and another hero Tom thought it was too simple, not stimulation enough. In this way, so that the reader's original calm feelings suddenly tense up, causing readers thought that can smoothly save affection fall down, and become more anxious. Then the author let the reader know that Tom's hard and tortuous way: to steal Jim out. Here, "save" becomes "steal". So, the reader's attention will turn into "how to steal Jim". And when we see a specific implementation plan, the heart can not help bursting into a happy smile; the tense feeling of readers is replaced by a kind of funny. As for Mark Twain, the suspense he made is just for creating a sense of humor, a straightforward atmosphere of the novel, not to add the number of charm, He just want to express his understanding of the suffering of the real world, and hope to remove the sadness in people's heart through humor, also return our life some happy and relaxed, but also some little sunshine.

\section{B. Pungent and Sarcastic Humor}

Mark Twain's humor has rational consciousness, in his humor, people not only can enjoy the pleasure of laugh, the value of laugh., the true of laugh, but also be able to comprehend the thoughts and feelings of Mark Twain. He often shows us with humor in superficial, and irony in essential, to expose and criticize the powerful evil in the American society. Through humor he expressed his attitude toward the world's critical attitude and the spirit of the question. In his The Celebrated Jumping Frog of Calaveras County, through the carefully painted of the hero's funny behavior, launched on the society some bad habits also showed us the humanity exploration clues of Mark Twain. The novel is talking about a layman how to deceive all the weak, deceive the strong and victory (Mark Twain, 2013). The most important was that people saw the author's mocking to Smiley through the superb art of humor of Mark Twain; saw a weakness of human nature. This is not only a ridiculous one for Smiley, more of the intention of the author is to let people see their inner psychological speculation, to remind people should keep a mind.

In fact, the author's purpose is to let people see the social system's unreasonable, see the evil of US policy of racial discrimination in American Society, see the state of ugliness. At the same time, also shows that Mark Twain tried to use humor to rebel and change the thought of bad social phenomenon. Around 90s, Mark Twain's humor creation has undergone great changes, his eyes became more and more sensitive, and his writing became extremely sharp. The novel The Man That Corrupted Hadley Burg that created in 1990 was a work which Mark Twain used the funny art to criticize money, and it is a reflection of human nature and the exploration of human society. Mark Twain (2013) reveals the fact that people will obey the willing of God, but more will listen to the money, money can control people lying, extortion or killing, money is supreme. Mark Twain used humor to write this novel is agree with the social background, and without prior without previous consultation, the virtue of honesty is cannot withstand a single blow, face to money, the small town eventually became the victim of the money, which is reasonable, especially the sentence at the end of the novel: "do not let me have the temptation is same as let us have the temptation", it can be described as sharp and humorous criticism toe social phenomenon at this point that kind of money is worship, Mark Twain to reflect on the full reality of American society, reflects the so-called democratic equality and freedom of the political system and the money. The social values of "humor is rebellious". Indeed, from Mark Twain's humor, we can see Mark Twain this personal emotion humor which is a denial of vulgar emotion, is also a kind of love that unwilling to live such a life, is a kind of emotion the author placed against the ideal of social life. 


\section{CONCLUSION}

\section{A. The Influence of Humor on the Later Novels}

A work to become a classic masterpiece and long-lasting, there are a variety of reasons, the most two important reasons: one is the content of the works reflect the characteristics of a particular era of culture and ideology, give historical value or the value of knowledge to a person, two is that works' originality in art, to give people a sense of beauty or provides a new craftsmanship, Mark Twain's novels got achievements in both content and art, especially the spirit of humor with critical novels shows that the unique art of humor has a far-reaching impact on later literature. Mark Twain is an outstanding American novelist, he stood in the democratic position, with humor and Banter humorous and funny style, depicting the social picture of the second half of the nineteenth Century the United States at the resplendent with variegated coloration, hit hard American Society of evil. In his novels, people often feel happy and humorous; also can feel the bitterness behind the happy. It is a bitterness generated by humor, and it is also a social disappointment, even bitterness against the social evils, but such bitterness generated by humor ultimate achievement of Mark Twain's humor spirit. Because of this spirit, Mark Twain can use humor to criticize the evil, expose the ugly and irony false. The spirit of humor is actually a kind of criticism, reflection and exploration of the real society and the human spirit. Humor is the tradition of American literature, many literary works show the characteristics, can use humor as a kind of spirit, use humor as a satire and criticism, reflection form, or start from the Mark Twain. Also it is because of this spirit of humor, from that time American literature get rid of European literature, and have their real local literature. It is starting from here; Mark Twain was later regarded as the father of American literary realism, great development of his spirit of humor impact on later literature. Faulkner is a great writer in the history of American literature, which known as a comedy master in our age. His novels have a strong regional, but also have a strong sense of humor. Black humor is popular in American literary genre in the 1970s. This genre writers believe that traditional writing cannot express social irrationality and the absurdity of the world, and they on social evils, cruel and exaggerated figures or events to be crazy dramatic to cold, using sharp humor to express their despair to the social reality.

\section{B. The Inheritance and Development of Twain Mark's Humor}

First of all, Mark Twain is the outstanding representative of the United States in the late nineteenth Century critical realism literature. He inherits the western literary tradition of humor, formed its own unique art of humor, and by the art of humor, attack the rule of American capitalist society money power, political corruption, moral hypocrisy, hypocrisy religion, insatiable greed and so on by the banter of ridicule and violent . In addition, Mark Twain invented the colloquial style of literature; this style of writing not only produces humorous effect, but also the sign of the real American literature form, and had a profound impact on American national literature. Prior to the American literature by European literary influence, require the writers to use standard elegant and gorgeous English words in creation, because frivolous style can ruin a piece of life of a work. Mark Twain was unconventional, pioneered the colloquial style of humorous literature. In his novels, he abandoned the gorgeous words, directly used Native American dialects, and laid a solid foundation for the development of American literature colloquial the style of writing. the dialect from the folk American that buried dip people's wisdom and feelings, with strong characteristics of humor, with a strong emotional color. Mark Twain set an example for future generations of writers. This mainly must maintain a serious tone and poker-faced without showing feelings on humor. It has different approaches but equally satisfactory results without previous agreement to the later advocated that the creation of the kind of calm and objective silent narration by American Modernist Literature. The narrative can reduce the subjective feelings, not too much influence from outside, so the story seems to be quite true, as has happened in life. Mark Twain advocated the serious tone of humor undoubtedly has a great reference to American literature for the requirements objectively describes. Finally, the use of humor logic dislocation, the logic of dislocation, as the name implies, refers to the logical thinking of each other is wrong, the two irrelevant things together, resulting in a subjective and objective uncoordinated, In order to achieve a mockery of the intention, Twain Mark's literary practice has a significant impact on the development of later literature, especially the black humor literature. Mark Twain let the world understand the humor with his wisdom, also let the world understand as a writer should have deep and broad mindedness. His creation, push the American literary realism in nineteenth Century to a peak of the world, the art of humor shown in the works always be treasures of mankind, his creation mercilessly criticized the American in all aspects of society, became a reliable witness of history; his creation, greatly inspired a large number of the later generations of litterateurs who loyal to the people, loyal to the art of literature, and promoted the development of American literature, world literature wrote a glorious page.

\section{REFERENCES}

[1] Chen zhijing. (2011). On Mark Twain and American humorous literature, Times literature, (12), 26-28.

[2] Mark Twain. (2012). The Celebrated Jumping Frog of Calaveras County, American: The Classics.us.

[3] Mark Twin. (2013). The Man Corrupted Hadley Burg, Rare Book Club.com.

[4] Wang Xue. (2014). Rhetorical analysis of humor in Mark Twain's representative short stories. Hubei: Yangtze university.16-24.

[5] Zeng Xi. (1995). Light and humorous reflection -- Mark Twain's artistic personality, Journal of Guangxi University, (05), 45-47. 
Ling Wang was born in1967 in Jian, China. She received her bachelor of Art degree in linguistics from Jiangxi Normal University, China in 1995.

She is currently an associate professor in the School of Foreign Languages, Nanchang Normal University, Nanchang, China. Her research interests include cross-cultural teaching and teaching methods.

Prof. Wang is a member of the Chinese Association of Foreign Language Teacher. 